\title{
Article \\ Defining Whole Grain Sorghum Flour and Water Levels to Improve Sensory and Nutritional Quality of Gluten-Free Bread-A Factorial Design Approach
}

\author{
Ana Carolina L. Centeno ${ }^{1}$, Etiene Aguiar ${ }^{1}$, Fernanda Santos ${ }^{1}\left(\mathbb{D}\right.$, Valéria Queiroz $^{2}$, Ana Conti-Silva ${ }^{3}$, \\ Urszula Krupa-Kozak $4, *$ (D) and Vanessa Capriles $1, *$ (D) \\ 1 Laboratory of Food Technology and Nutrition, Department of Biosciences, Campus Baixada Santista, \\ Institute of Health and Society, Federal University of São Paulo, Santos 11015-020, Brazil; \\ anacladeia@gmail.com (A.C.L.C.); etiene.aguiar@unifesp.br (E.A.); fg.santos@unifesp.br (F.S.) \\ 2 Brazilian Agricultural Research Corporation (Embrapa) Milho e Sorgo, Sete Lagoas 35701-970, Brazil; \\ valeria.vieira@embrapa.br \\ 3 Department of Food Engineering and Technology, Humanities and Exact Sciences (Ibilce), Campus São José \\ do Rio Preto, Institute of Biosciences, São Paulo State University, São José do Rio Preto 15054-000, Brazil; \\ conti.silva@unesp.br \\ 4 Department of Chemistry and Biodynamics of Food, Institute of Animal Reproduction and Food Research of \\ Polish Academy of Sciences, 10-748 Olsztyn, Poland \\ * Correspondence: urszula.krupa@pan.olsztyn.pl (U.K.-K.); vanessa.capriles@unifesp.br (V.C.)
}

Citation: Centeno, A.C.L.; Aguiar, E.; Santos, F.; Queiroz, V.; Conti-Silva, A.; Krupa-Kozak, U.; Capriles, V. Defining Whole Grain Sorghum Flour and Water Levels to Improve Sensory and Nutritional Quality of

Gluten-Free Bread-A Factorial Design Approach. Appl. Sci. 2021, 11, 8186. https://doi.org/10.3390/ app11178186

Academic Editor:

Anabela Raymundo

Received: 2 August 2021

Accepted: 31 August 2021

Published: 3 September 2021

Publisher's Note: MDPI stays neutral with regard to jurisdictional claims in published maps and institutional affiliations.

Copyright: (c) 2021 by the authors Licensee MDPI, Basel, Switzerland. This article is an open access article distributed under the terms and conditions of the Creative Commons Attribution (CC BY) license (https:// creativecommons.org/licenses/by/ $4.0 /)$.

\begin{abstract}
This study aims to investigate the potential of white and bronze whole-grain sorghum flour to develop gluten-free bread (GFB) with acceptable sensory properties. Two $2^{2}$ factorial designs, with two central point repetitions each, were used to study the effects of white (WS) or bronze sorghum (BS) flours and water (W) levels on the physical properties, acceptability scores, and proximate composition of GFB. The WS or BS levels ranged from 50 to $100 \%$ when blended with potato starch, and the $\mathrm{W}$ levels ranged from 100 to $140 \%$ (flour weight basis). Independent of the amount applied, GFB formulations containing BS were well accepted (acceptability scores for appearance, color, odor, texture, flavor and overall liking $\geq 6.29$ on a $10 \mathrm{~cm}$ hybrid hedonic scale). No significant differences were observed between the acceptability scores of single and composite formulations for all of the evaluated sensory attributes. Moreover, the $\mathrm{W}$ levels had no effect on the acceptability of GFB made with BS. Composite formulations prepared with 50 and 75\% WS were also well accepted (acceptability scores for appearance, color, odor, texture, flavor, and overall liking $\geq 7.43$ on a $10 \mathrm{~cm}$ hybrid hedonic scale). However, increased $\mathrm{W}$ levels are required in single formulations to increase the scores for texture and overall acceptability. GFB made with 50\% and 75\% WS/BS can be classified as a source of fiber since the fiber content is higher than $3 \mathrm{~g}$ per $100 \mathrm{~g}$, while GFB made with $100 \%$ WS/BS can be classified as high in fiber, as the content of this component is higher than $6 \mathrm{~g}$ per $100 \mathrm{~g}$. This research highlights the great potential of whole-grain sorghum flours for producing nutrient-dense and acceptable GFB, which is important for consumers who choose or must adhere to a GF diet.
\end{abstract}

Keywords: gluten-free bread; Sorghum bicolor; whole grains; sensory acceptance; multiple factor analysis

\section{Introduction}

Several studies concerning the gluten-free bread (GFB) available on the market have shown low levels of protein and micronutrients and high levels of lipid and sodium compared to similar products made with wheat flour. These features, in addition to the lack of enrichment or fortification, negatively contribute to the health of individuals with a gluten-restricted diet [1-6]. Our recent overview showed that over the last ten years, multiple gluten-containing (GC; $n=7122)$ and gluten-free (GF; $n=3153)$ food products have been investigated and compared worldwide [1]. Results for GFB ( $n=935)$ show 
that it is composed of numerous raw ingredients and additives that result in an extensive variability in the contents of carbohydrates (14-84\%), fat (1-19\%), proteins (0-11\%), sugar $(0-24 \%)$, and dietary fiber $(0-17 \%)$. These products are still recognized as being high in fat, low in protein content, and, in some cases, also low in dietary fiber.

In addition to the lack of nutritional content, GFB is generally recognized as a product with poor texture, dry mouthfeel, and poor taste $[1,5,6]$. Therefore, sensory and nutritional aspects are key issues to be addressed in the development of healthier GFBs that can meet quality requirements [1].

To address this problem, the use of alternative raw materials, such as whole-grain sorghum flour (SF), which is rich in nutrients and bioactive compounds, has been recommended [1]. Originating in Africa, sorghum is the fifth most-produced cereal worldwide [7]. Sorghum has a high potential for grain production in addition to its extraordinary ability to withstand environmental stresses, making it an excellent option for grain production in water deficit situations and low soil fertility [8]. Compared to other cereals, such as oats, rice, and wheat, sorghum has higher concentrations of total phenolic compounds, such as tannins, showing a greater antioxidant capacity $[9,10]$. Sorghum also stands out as a good source of dietary fiber, iron, phosphorus, magnesium, and zinc [11].

Researchers have reported good results in terms of the physical properties of GFB made from sorghum flour (SF) alone or blended with other non-gluten flours or starches [12-14]. Authors have also shown the potential of sorghum to develop food products with a sensory and nutritional appeal since these products made with SF were well accepted by consumers and can contribute to human health $[15,16]$. GFB made with SF had higher protein, dietary fiber, total phenol contents and higher antioxidant properties than GFB prepared with rice flour (RF), which is one of the main ingredients used in commercial GFB [6,17]. However, most studies have been conducted with bronze sorghum (BS), and it is also important to evaluate the potential of other varieties, such as white sorghum (WS).

The literature has shown the need to increase the water content of GFB formulations enriched with dietary fiber and/or protein or with other raw materials that are sources of these components because of the high water retention capacity of these ingredients. Increasing the water content is important to ensure appropriate conditions for the dough viscosity, starch gelatinization, and protein denaturation during the breadmaking process [18]. The amount of water must be individually adjusted for each formulation while considering the proportion of ingredients in the formulation and the process conditions. In recent publications, a maximum of $120 \%$ water (flour weight basis) was used in GFB formulations using up to $70 \%$ sorghum flour $[13-16,19,20]$. Investigation of higher sorghum and water content levels has not been often explored. Therefore, the present study aimed to investigate whether increased water content allows the use of higher levels of whole-grain SF to obtain GFB with better nutritional, physical, and sensory properties.

\section{Materials and Methods}

\subsection{Materials}

WS (BR 501) and BS (BRS 332) grains, supplied by Embrapa Maize and Sorghum (Sete Lagoas, Brazil), were transported to the Federal University of São Paulo (UNIFESP, Santos, Brazil) and were milled in a laboratory mill (Laboratory Mill 3303, Perten Instruments, Segeltorp, Sweden) to level 0, which is the lowest grinding mill level, obtaining finely milled whole flours. Fine flour was used in order to not produce and to minimize the sandy mouthfeel, which is often reported for GFB prepared with whole grain flour, according to the literature review by Capriles and Arêas [18].

The particle size distribution was 58\% $425 \mu \mathrm{m}, 33 \% 250 \mu \mathrm{m}, 8 \% 180 \mu \mathrm{m}$, and $1 \% \leq 150 \mu \mathrm{m}$ for WS; $68 \% 425 \mu \mathrm{m}, 26 \% 250 \mu \mathrm{m}, 4 \% 180 \mu \mathrm{m}$, and $2 \% \leq 150 \mu \mathrm{m}$ for BS; and $4 \% 425 \mu \mathrm{m}$, $29 \% 250 \mu \mathrm{m}, 31 \% 180 \mu \mathrm{m}$, and $36 \% \leq 150 \mu \mathrm{m}$ for potato starch (PS). The analysis was performed according to the AOAC method 965.2 [21].

WS contains (\%, dry basis) 64.1 available carbohydrates, 17.3 dietary fiber, 12.0 protein, 5.0 lipids, and 1.6 ash. BS contains (\%, dry basis) 65.5 available carbohydrates, 16.7 dietary 
fiber, 11.8 protein, 4.8 lipids, and 1.2 ash. PS contains (\%, dry basis) 98.9 available carbohydrates, 0.5 dietary fiber, 0.0 protein, 0.0 lipids, and 0.3 ash. These contents were determined using standard AOAC methods [21], as described in Section 2.2.2.

Xanthan gum (Ziboxan F80, Deosen Biochemical Ltd. (21), Shandong, China) was donated by Vogler Ingredients Ltda (São Bernardo do Campo, Brazil), and carboxymethylcellulose (Denvercel FG-2504A, Denver Especialidades Químicas Ltda, Cotia, Brazil) was donated by the manufacturer. The other ingredients were purchased at the local market.

\subsection{Methods}

\subsubsection{Factorial Design and Preparation of Gluten-Free Breads}

Two $2^{2}$ (sorghum flours $x$ water level) factorial designs with two central point replications each were applied to study the effects of WS/BS and W level and their interactions with the physical properties, sensory acceptability, and proximate composition of GFB. The levels of the WS and BS flours ranged from 50 to $100 \%$ when blended with PS, and W ranged from 100 to $140 \%$ on a flour weight basis (fwb). A total of six formulations were produced for each design: four were related to factorial points (combinations of the variables in the encoded levels -1 and +1 ), and two were centroid point replications (variables in the encoded levels 0 and 0 ), which were created using a randomized execution sequence.

Regarding the $\% \mathrm{fwb}$, the GFB formulation consisted of the following: 100\% flour/starch blend, $25 \%$ whole egg, $10.5 \%$ whole milk powder, $6 \%$ white cane sugar, $6 \%$ soy oil, $2 \%$ salt, $0.8 \%$ dry yeast, $0.3 \%$ xanthan gum, and $0.3 \%$ carboxymethylcellulose, according to Sandri et al. [22] and Santos et al. [23]. Thus, the fwb consisted of WS or BS flours alone or blended with PS, according to the factorial design. The lower and upper limits of SF and W were confirmed in previous bakery trials.

The straight dough method was used to make the bread. Initially, all of the ingredients were mixed in a semi-industrial planetary mixer (Skymsen, Model BPS-05, Metalúrgica Siemsen Ltda, Brusque, Brazil) using a flat beater at $110 \mathrm{rpm}$ for $4 \mathrm{~min}$. Then, approximately $350 \mathrm{~g}$ of dough was placed in pans that had previously been greased and floured with rice flour (base of $17 \times 9 \mathrm{~cm}$ and height of $5 \mathrm{~cm}$ ), proofed in a controlled proofing chamber (CFK-10, Klimaquip S/A, Pouso Alegre, Brazil) at $40{ }^{\circ} \mathrm{C}$ with a relative humidity of $85 \%$ for $45 \mathrm{~min}$, and then baked in a convection oven for bread (HPE-80, Prática Produtos S.A., Pouso Alegre, Brazil) at $160^{\circ} \mathrm{C}$ for $22 \mathrm{~min}$. The bread was removed from the pans, cooled for $2 \mathrm{~h}$ at room temperature, packed in polypropylene bags, and stored $\left(23-25^{\circ} \mathrm{C}\right)$. The analyses were conducted up to $3 \mathrm{~h}$ after production.

\subsubsection{Bread Evaluation}

The evaluation of the physical properties consisted of loaf specific volume, crumb moisture, and crumb firmness. The loaf-specific volume was determined as the ratio between the bread volume and the weight, according to AACC method 10-05.01 [24]. The moisture content was determined in the center of each bread crumb by means of desiccation in an oven at $105^{\circ} \mathrm{C}$, according to AACC method 44-15A [24]. These analyses were performed in triplicate.

The crumb firmness was measured in a texturometer (TA. XTplus Texture Analyser, Stable Micro Systems, Godalming, United Kingdom), according to AACC method 74-09 [24]. The loaves were sliced crosswise in a manual bread slicer (Imeca Indústria Metalúrgica Ltda., Bauru, Brazil), resulting in 25-mm thick uniform slices. Texture measurements (six values) were performed on two bread slices that were taken from the centers of three different loaves.

Sensory analysis was conducted with consumers of traditional bread in four sessions: two for the evaluation of three WS formulations and two for the evaluation of three BS formulations. A total of fifty-two consumers 18-59 years of age participated in each session. All of the participants stated that they had no allergies or intolerances to any of the ingredients present in the products and were informed that they were evaluating GFB. The sessions were conducted in a sensory evaluation laboratory with climate control $\left(23-25^{\circ} \mathrm{C}\right)$ 
equipped with individual booths and white light, and the consumers were instructed to drink water between the samples to minimize residual effects. In each session, bread slices (12.5 mm thickness), similar to those in Figure 1, were offered in polyethylene bags coded with random three-digit numbers in complete balanced blocks and delivered to consumers in a monadic manner. Consumers evaluated the acceptability of the appearance, color, odor, texture, flavor, and their overall liking; in this sequence, the criteria were evaluated on a 10 -cm hybrid hedonic scale ( $0=$ disliked extremely, $5=$ neutral, $10=$ liked extremely) using a paper questionnaire [25].

The proximate composition of the GFB formulations (a bread loaf containing crumb and crust) was determined using AOAC methods [25]: moisture content based on weight loss after heating the sample in an oven at $105^{\circ} \mathrm{C}$; ash content by incineration in a muffle furnace at $550{ }^{\circ} \mathrm{C}$; protein content by total nitrogen obtained by the micro-Kjeldahl method, considering a conversion factor of $\% \mathrm{~N} \times 6.25$; and lipid content by the goldfish method. Total, soluble, and insoluble dietary fiber were determined by means of the enzymaticgravimetric method using AOAC method 991.43 [21] and the K-ACHDF analytical kit (Megazyme International Ireland Ltd., Bray, Ireland). The available carbohydrate content was calculated by difference $[100-$ (moisture + ash + protein + lipid + dietary fiber $)]$. The results were expressed as $\mathrm{g} / 100 \mathrm{~g}$ on a wet basis.

\subsubsection{Statistical Analysis}

All of results are expressed as the mean and standard deviation. The means of trial differences were identified by one-way analysis of variance (ANOVA) and the Tukey test. The model adequacies were checked by variance analysis (F test), R2 values, and diagnostic plots such as normal and residual plots [26]. The Statistica 12.0 software (StartSoft Inc., Tulsa, OK, USA) was used for these statistical analyses. Multiple factor analysis (MFA) was applied to verify the relationship between the three tables of variables (physical, sensory, and proximate composition properties). Hierarchical clustering analysis (HCA) was performed, and a dendrogram was produced based on the coordinates of the matrix of factors obtained by MFA considering Euclidean distances, Ward's method, automatic truncation, and the cophenetic correlation coefficient, using XLSTAT 2021.2 software (Addinsoft, New York, NY, USA). The significance level was set at 0.05 for all of the analyses.

\section{Results}

\subsection{Effects of Ingredients on the Physical-Chemical and Sensory Characterisctics of GFB}

Table 1 shows the experimental design values of the response variables to GFB based made with WS flour, while Table 2 shows the results obtained for GFB based made with BS flour.

According to the results presented in Table 1, there was no change in the loaf specific volume when the WS level was increased from 50\% to $100 \%$ in the fixed concentration of $100 \% \mathrm{~W}$ (trials 1 and 2, Table 1). However, when the WS level increased from 50\% to 100\% in the formulations with $140 \% \mathrm{~W}$, the loaf specific volume increased (trials 3 and 4, Table 1). This result indicates that at the highest $W$ concentration used in the design, the increase of WS provided the breads with a higher specific volume. Moreover, comparing Trials 1 with 2 and 3 with Trial 4 (Table 1) shows that the increase from 50\% to 100\% WS caused an increase crumb firmness. However, when comparing Trial 2 with Trial 4 (100\% WS), we observed that the increase from $100 \%$ to $140 \% \mathrm{~W}$ decreased crumb firmness values, which indicated that the water increase in the formulations prepared with WS only resulted in softer breads.

According to the results presented in Table 1, there was no change in the loaf specific volume when the WS level was increased from $50 \%$ to $100 \%$ in the fixed concentration of $100 \% \mathrm{~W}$ (Trials 1 and 2, Table 1). However, when the WS level increased from 50\% to 100\%, in the formulations with $140 \% \mathrm{~W}$, the loaf specific volume increased (Trials 3 and 4, Table 1). This result indicates that at the highest $W$ concentration used in the design, the increase in WS provided the breads with a higher specific volume. Moreover, comparing Trial 1 
with Trial 2 and Trial 3 with Trial 4 (Table 1) shows that the increase from $50 \%$ to $100 \%$ WS caused an increase in the crumb firmness. However, when comparing Trial 2 with Trial 4 (100\% WS), we observed that the W increase from 100\% to $140 \%$ decreased crumb firmness values, which indicated that the water increase in the formulations prepared with WS only resulted in softer bread.

In general, the breads prepared with WS achieved great acceptance, with scores ranging from 6.29 (texture to trial 2) to 8.89 (overall acceptability to trial 3). There were no significant differences in the scores for appearance and color acceptability, which shows that it is possible to use 50 to $100 \%$ WS without affecting the visual acceptability of GFB. The odor, texture, flavor, and overall acceptability were reduced when the WS was increased and when the W was fixed; however, when the W increased and when the WS was at fixed levels, no difference was observed (Table 1).

Additionally, the increase from 50 to $100 \%$ WS with $100 \% \mathrm{~W}$ (Trials 1 and 2) resulted in higher ash, protein, lipid, and fiber contents (Table 1). When comparing Trials 2 and 4, the increase in $\mathrm{W}$ from $100 \%$ to $140 \%$ did not result in significant differences in the proximate composition of GFB prepared with WS, except for the insoluble fiber content, which was lower in the GFB prepared with $100 \% \mathrm{~W}$ and $100 \% \mathrm{WS}$. Therefore, in general, it is possible to adjust the $\mathrm{W}$ content of GFB without affecting its composition.

As indicated in Table 2, a BS increase in bread made with 100\% W (Trials 1 and 2) provided an increase in the specific volume and a decrease in the crumb firmness, resulting in a softer crumb.

All of the GFBs prepared with BS were well accepted, with acceptability scores ranging from 7.43 (texture for trial 2, Table 2) to 8.65 (flavor for trial 3, Table 2). There were no significant differences in appearance, color, odor, texture, and overall scores. These results indicate that it is possible to use the highest concentration of BS and obtain bread with good acceptability. It is important to note that sensory analyses were performed with healthy subjects, and a good acceptability evaluation by this group implies a closer similarity to regular bread. However, further sensory investigations with GF food consumers, besides those of nutritional compositions, should be applied to verify whether any developed products will meet the requirements of those consumers. The increase of BS in the concentration of $100 \% \mathrm{~W}$ (Trials 1 and 2 ) resulted in higher ash, protein, lipid, and dietary fiber contents (Table 2).

As observed for the composition of GFB with WS (Table 1), the GFB prepared with BS (Table 2) showed no reduction in ash, protein, and total fiber values when the $W$ level was increased from $100 \%$ to $140 \%$, while the insoluble fiber content decreased. 


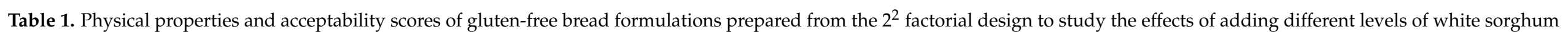
(WS) flour and water (W).

\begin{tabular}{|c|c|c|c|c|c|c|c|c|c|c|c|c|c|c|c|c|c|c|c|}
\hline \multirow[b]{2}{*}{ Trial } & \multicolumn{2}{|c|}{$\begin{array}{l}\text { Coded Levels } \\
\text { (Real Values) }\end{array}$} & \multicolumn{3}{|c|}{ Physical Properties } & \multicolumn{6}{|c|}{ Acceptability Scores on the $10 \mathrm{~cm} \mathrm{Scale}{ }^{3}$} & \multicolumn{8}{|c|}{ Centesimal Composition ( $\mathrm{g} / \mathbf{1 0 0} \mathrm{g}$ in Wet Base) } \\
\hline & wS & W & $\begin{array}{l}\text { Specific } \\
\text { Volume } \\
\left(\mathrm{cm}^{3} / \mathrm{g}\right)^{1}\end{array}$ & $\begin{array}{c}\text { Cumb } \\
\text { Firmness } \\
(\mathrm{N})^{2}\end{array}$ & $\begin{array}{c}\text { Crumb } \\
\text { Moisture } \\
(\%)^{1}\end{array}$ & Appearance & Color & Odor & Texture & Flavor & Overall & Moisture & Ash & Protein & Lipid & $\begin{array}{c}\text { Total } \\
\text { Dietary } \\
\text { Fiber }\end{array}$ & $\begin{array}{l}\text { Insoluble } \\
\text { Fiber }\end{array}$ & $\begin{array}{l}\text { Soluble } \\
\text { Fiber }\end{array}$ & $\begin{array}{c}\text { Available } \\
\text { Carbohydrates }\end{array}$ \\
\hline 1 & $\begin{array}{c}-1 \\
(50 \%)\end{array}$ & $\begin{array}{c}-1 \\
(100 \%)\end{array}$ & $\begin{array}{l}1.93^{\mathrm{a}} \\
\pm 0.02\end{array}$ & $\begin{array}{c}16.66^{\mathrm{bc}} \\
\pm 1.22\end{array}$ & $\begin{array}{l}53.92^{\mathrm{d}} \\
\pm 0.19\end{array}$ & $\begin{array}{l}8.50^{\mathrm{a}} \\
\pm 1.59\end{array}$ & $\begin{array}{l}8.44^{\mathrm{a}} \\
\pm 1.65\end{array}$ & $\begin{array}{l}8.75^{\mathrm{a}} \\
\pm 1.45\end{array}$ & $\begin{array}{l}7.90^{\mathrm{ab}} \\
\pm 1.73\end{array}$ & $\begin{array}{l}8.10^{\text {ab }} \\
\pm 1.55\end{array}$ & $\begin{array}{l}8.13^{\mathrm{ab}} \\
\pm 1.47\end{array}$ & $\begin{array}{l}47.49^{c} \\
\pm 0.16\end{array}$ & $\begin{array}{l}0.84^{\mathrm{b}} \\
\pm 0.02\end{array}$ & $\begin{array}{l}5.10^{\mathrm{b}} \\
\pm 0.22\end{array}$ & $\begin{array}{l}5.01^{\mathrm{b}} \\
\pm 0.09\end{array}$ & $\begin{array}{c}4.73^{\mathrm{d}} \pm \\
0.17\end{array}$ & $\begin{array}{l}3.82^{\mathrm{d}} \\
\pm 0.29\end{array}$ & $\begin{array}{l}0.91^{\mathrm{b}} \\
\pm 0.15\end{array}$ & 36.83 \\
\hline 2 & $\begin{array}{c}+1 \\
(100 \%)\end{array}$ & $\begin{array}{c}-1 \\
(100 \%)\end{array}$ & $\begin{array}{l}1.9^{\mathrm{a}} \\
\pm 0.01\end{array}$ & $\begin{array}{l}21.83^{\mathrm{a}} \\
\pm 0.69\end{array}$ & $\begin{array}{l}52.98^{\mathrm{e}} \\
\pm 0.11\end{array}$ & $\begin{array}{l}7.94^{\mathrm{a}} \\
\pm 1.83\end{array}$ & $\begin{array}{l}7.73^{\mathrm{a}} \\
\pm 1.89\end{array}$ & $\begin{array}{l}7.58^{\mathrm{b}} \\
\pm 1.85\end{array}$ & $\begin{array}{l}6.29^{c} \\
\pm 2.11\end{array}$ & $\begin{array}{l}6.74^{c} \\
\pm 2.33\end{array}$ & $\begin{array}{l}6.86^{\mathrm{c}} \\
\pm 1.94\end{array}$ & $\begin{array}{l}47.22^{\mathrm{c}} \\
\pm 0.08\end{array}$ & $\begin{array}{l}0.93^{\mathrm{a}} \\
\pm 0.02\end{array}$ & $\begin{array}{l}6.62^{\mathrm{a}} \\
\pm 0.06\end{array}$ & $\begin{array}{l}5.25^{\mathrm{a}} \\
\pm 0.10\end{array}$ & $\begin{array}{c}8.26^{\mathrm{a}} \pm \\
0.17\end{array}$ & $\begin{array}{l}6.68^{\mathrm{a}} \\
\pm 0.15\end{array}$ & $\begin{array}{l}1.58^{\mathrm{a}} \\
\pm 0.08\end{array}$ & 31.72 \\
\hline 3 & $\begin{array}{c}-1 \\
(50 \%)\end{array}$ & $\begin{array}{c}+1 \\
(140 \%)\end{array}$ & $\begin{array}{l}1.57^{c} \\
\pm 0.01\end{array}$ & $\begin{array}{l}14.17^{\mathrm{d}} \\
\pm 1.10\end{array}$ & $\begin{array}{l}60.23^{\mathrm{a}} \\
\pm 0.38\end{array}$ & $\begin{array}{l}8.46^{\mathrm{a}} \\
\pm 1.39\end{array}$ & $\begin{array}{l}8.58^{\mathrm{a}} \\
\pm 1.36\end{array}$ & $\begin{array}{l}8.61^{\mathrm{a}} \\
\pm 1.59\end{array}$ & $\begin{array}{l}8.41^{\text {a }} \\
\pm 1.61\end{array}$ & $\begin{array}{l}8.74^{\mathrm{a}} \\
\pm 1.33\end{array}$ & $\begin{array}{l}8.89^{\mathrm{a}} \\
\pm 1.39\end{array}$ & $\begin{array}{l}53.27^{\mathrm{a}} \\
\pm 0.08\end{array}$ & $\begin{array}{l}0.86^{\mathrm{b}} \\
\pm 0.02\end{array}$ & $\begin{array}{l}5.17^{\mathrm{b}} \\
\pm 0.23\end{array}$ & $\begin{array}{l}5.08 \mathrm{ab} \\
\pm 0.09\end{array}$ & $\begin{array}{c}4.21^{\mathrm{d}} \pm \\
0.15\end{array}$ & $\begin{array}{l}3.40^{\mathrm{d}} \\
\pm 0.26\end{array}$ & $\begin{array}{l}0.81^{\mathrm{b}} \\
\pm 0.13\end{array}$ & 31.41 \\
\hline 4 & $\begin{array}{c}+1 \\
(100 \%)\end{array}$ & $\begin{array}{c}+1 \\
(140 \%)\end{array}$ & $\begin{array}{l}1.84^{\mathrm{b}} \\
\pm 0.02\end{array}$ & $\begin{array}{l}17.34^{\mathrm{b}} \\
\pm 0.53\end{array}$ & $\begin{array}{l}59.29^{\mathrm{b}} \\
\pm 0.05\end{array}$ & $\begin{array}{l}8.21^{\mathrm{a}} \\
\pm 1.56\end{array}$ & $\begin{array}{l}7.99^{\mathrm{a}} \\
\pm 1.72\end{array}$ & $\begin{array}{l}8.01 \mathrm{ab} \\
\pm 1.63\end{array}$ & $\begin{array}{l}7.17 \mathrm{bc} \\
\pm 2.35\end{array}$ & $\begin{array}{l}7.69 \mathrm{bc} \\
\pm 1.71\end{array}$ & $\begin{array}{l}7.60 \mathrm{bc} \\
\pm 1.75\end{array}$ & $\begin{array}{l}53.29^{\mathrm{a}} \\
\pm 0.05\end{array}$ & $\begin{array}{l}0.94^{\mathrm{a}} \\
\pm 0.02\end{array}$ & $\begin{array}{l}6.68^{\mathrm{a}} \\
\pm 0.06\end{array}$ & $\begin{array}{l}5.30^{\mathrm{a}} \\
\pm 0.10\end{array}$ & $\begin{array}{c}7.30^{\mathrm{b}} \pm \\
0.15\end{array}$ & $\begin{array}{l}5.91^{\mathrm{b}} \\
\pm 0.14\end{array}$ & $\begin{array}{l}1.39^{\mathrm{a}} \\
\pm 0.07\end{array}$ & 26.49 \\
\hline 5 & \multirow{2}{*}{$\begin{array}{c}0 \\
(75 \%)\end{array}$} & \multirow{2}{*}{$\begin{array}{c}0 \\
(120 \%)\end{array}$} & $\begin{array}{l}1.89 \mathrm{ab} \\
\pm 0.03\end{array}$ & $\begin{array}{c}16.25 \mathrm{bc} \\
\pm 1.12\end{array}$ & $\begin{array}{l}56.67^{\mathrm{c}} \\
\pm 0.15\end{array}$ & $\begin{array}{l}8.29 \text { a } \\
\pm 1.72\end{array}$ & $\begin{array}{l}8.24^{\mathrm{a}} \\
\pm 1.74\end{array}$ & $\begin{array}{l}8.49^{\mathrm{a}} \\
\pm 1.66\end{array}$ & $\begin{array}{l}7.61 \mathrm{ab} \\
\pm 1.90\end{array}$ & $\begin{array}{l}8.15^{\mathrm{ab}} \\
\pm 1.82\end{array}$ & $\begin{array}{l}8.15 \mathrm{ab} \\
\pm 1.55\end{array}$ & \multirow{2}{*}{$\begin{array}{l}51.39^{\mathrm{b}} \\
\pm 0.29\end{array}$} & \multirow{2}{*}{$\begin{array}{l}0.74^{\mathrm{c}} \\
\pm 0.02\end{array}$} & \multirow{2}{*}{$\begin{array}{l}5.35^{\mathrm{b}} \\
\pm 0.06\end{array}$} & \multirow{2}{*}{$\begin{array}{l}5.14 \text { ab } \\
\pm 0.04\end{array}$} & \multirow{2}{*}{$\begin{array}{c}5.76^{c} \pm \\
0.51\end{array}$} & \multirow{2}{*}{$\begin{array}{l}4.76^{c} \\
\pm 0.44\end{array}$} & \multirow{2}{*}{$\begin{array}{l}1.00^{\mathrm{b}} \\
\pm 0.13\end{array}$} & \multirow[b]{2}{*}{31.62} \\
\hline 6 & & & $\begin{array}{l}1.88 \mathrm{ab} \\
\pm 0.01\end{array}$ & $\begin{array}{c}15.53^{\text {cd }} \\
\pm 0.72\end{array}$ & $\begin{array}{l}56.99^{c} \\
\pm 0.08\end{array}$ & $\begin{array}{l}8.26^{\mathrm{a}} \\
\pm 1.72\end{array}$ & $\begin{array}{l}8.10^{\mathrm{a}} \\
\pm 1.75\end{array}$ & $\begin{array}{l}8.633^{a} \\
\pm 1.48\end{array}$ & $\begin{array}{l}7.56^{\mathrm{ab}} \\
\pm 1.98\end{array}$ & $\begin{array}{l}8.00 \text { ab } \\
\pm 2.10\end{array}$ & $\begin{array}{l}8.21 \text { ab } \\
\pm 1.57\end{array}$ & & & & & & & & \\
\hline
\end{tabular}

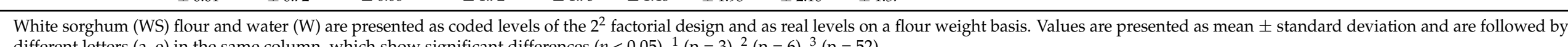
different letters $(\mathrm{a}-\mathrm{e})$ in the same column, which show significant differences $(p<0.05) .{ }^{1}(\mathrm{n}=3),{ }^{2}(\mathrm{n}=6),{ }^{3}(\mathrm{n}=52)$. 


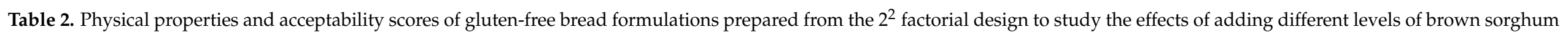
(BS) flour and water (W).

\begin{tabular}{|c|c|c|c|c|c|c|c|c|c|c|c|c|c|c|c|c|c|c|c|}
\hline \multirow[b]{2}{*}{ Trial } & \multicolumn{2}{|c|}{$\begin{array}{l}\text { Coded Levels } \\
\text { (Real Values) } \\
\end{array}$} & \multicolumn{3}{|c|}{ Physical Properties } & \multicolumn{6}{|c|}{ Acceptability Scores on the $10 \mathrm{~cm} \mathrm{Scale}{ }^{3}$} & \multicolumn{8}{|c|}{ Centesimal Composition ( $\mathrm{g} / 100 \mathrm{~g}$ in Wet Base) } \\
\hline & BS & W & $\begin{array}{c}\text { Specific } \\
\text { Volume } \\
\left(\mathrm{cm}^{3} / \mathrm{g}\right)^{1}\end{array}$ & $\begin{array}{l}\text { Cumb } \\
\text { Firmness } \\
\left(^{(N)^{2}}\right.\end{array}$ & $\begin{array}{c}\text { Crumb } \\
\text { Moisture } \\
(\%)^{1}\end{array}$ & Appearance & Color & Odor & Texture & Flavor & Overall & Moisture & Ash & Protein & Lipid & $\begin{array}{c}\text { Total } \\
\text { Dietary } \\
\text { Fiber }\end{array}$ & $\begin{array}{l}\text { Insoluble } \\
\text { Fiber }\end{array}$ & $\begin{array}{l}\text { Soluble } \\
\text { Fiber }\end{array}$ & $\begin{array}{l}\text { Available } \\
\text { Carbohydrate }\end{array}$ \\
\hline 2 & $\begin{array}{c}+1 \\
(100 \%)\end{array}$ & $\begin{array}{c}-1 \\
(100 \%)\end{array}$ & $\begin{array}{l}1.90^{\mathrm{a}} \\
\pm 0.02\end{array}$ & $\begin{array}{l}15.62^{\mathrm{b}} \\
\pm 0.86 \\
\end{array}$ & $\begin{array}{l}53.68^{\mathrm{c}} \\
\pm 0.13\end{array}$ & $\begin{array}{l}8.33^{\mathrm{a}} \\
\pm 1.76 \\
\end{array}$ & $\begin{array}{l}8.33^{\mathrm{a}} \\
\pm 1.64 \\
\end{array}$ & $\begin{array}{l}8.33^{\mathrm{a}} \\
\pm 2.03 \\
\end{array}$ & $\begin{array}{l}7.43^{\mathrm{a}} \\
\pm 1.93 \\
\end{array}$ & $\begin{array}{l}7.51 \mathrm{~b} \\
\pm 2.15 \\
\end{array}$ & $\begin{array}{l}7.72^{\mathrm{a}} \\
\pm 1.80 \\
\end{array}$ & $\begin{array}{l}46.89^{\mathrm{b}} \\
\pm 0.06 \\
\end{array}$ & $\begin{array}{l}0.90^{\mathrm{a}} \\
\pm 0.01\end{array}$ & $\begin{array}{l}7.24^{\mathrm{a}} \\
\pm 0.10 \\
\end{array}$ & $\begin{array}{l}5.35^{\mathrm{a}} \\
\pm 0.10 \\
\end{array}$ & $\begin{array}{c}7.46^{\mathrm{a}} \pm \\
0.33\end{array}$ & $\begin{array}{l}6.27^{\mathrm{a}} \\
\pm 0.33 \\
\end{array}$ & $\begin{array}{l}1.19^{\mathrm{a}} \\
\pm 0.06\end{array}$ & 32.16 \\
\hline 3 & $\begin{array}{c}-1 \\
(50 \%)\end{array}$ & $\begin{array}{c}+1 \\
(140 \%)\end{array}$ & $\begin{array}{l}1.71^{\mathrm{b}} \\
\pm 0.06 \\
\end{array}$ & $\begin{array}{c}13.92 \mathrm{bc} \\
\pm 1.29 \\
\end{array}$ & $\begin{array}{l}60.09^{\text {a }} \\
\pm 0.31 \\
\end{array}$ & $\begin{array}{l}7.77^{\mathrm{a}} \\
\pm 1.90 \\
\end{array}$ & $\begin{array}{l}7.56^{\mathrm{a}} \\
\pm 2.05 \\
\end{array}$ & $\begin{array}{l}8.50^{\mathrm{a}} \\
\pm 1.65 \\
\end{array}$ & $\begin{array}{l}8.40^{\mathrm{a}} \\
\pm 1.83 \\
\end{array}$ & $\begin{array}{l}8.65^{\mathrm{a}} \\
\pm 1.71 \\
\end{array}$ & $\begin{array}{l}8.48^{\mathrm{a}} \\
\pm 1.61 \\
\end{array}$ & $\begin{array}{l}54.21^{\mathrm{a}} \\
\pm 0.23 \\
\end{array}$ & $\begin{array}{l}0.83^{\mathrm{b}} \\
\pm 0.01 \\
\end{array}$ & $\begin{array}{l}4.86^{\mathrm{c}} \\
\pm 0.09 \\
\end{array}$ & $\begin{array}{l}5.30^{\mathrm{a}} \\
\pm 0.20 \\
\end{array}$ & $\begin{array}{c}4.30^{\mathrm{d}} \pm \\
0.17\end{array}$ & $\begin{array}{l}3.34^{\mathrm{d}} \\
\pm 0.15 \\
\end{array}$ & $\begin{array}{l}0.96^{\mathrm{b}} \\
\pm 0.10 \\
\end{array}$ & 30.50 \\
\hline 4 & $\begin{array}{c}+1 \\
(100 \%)\end{array}$ & $\begin{array}{c}+1 \\
(140 \%)\end{array}$ & $\begin{array}{l}1.74^{\mathrm{b}} \\
\pm 0.03 \\
\end{array}$ & $\begin{array}{l}15.65^{\mathrm{b}} \\
\pm 1.85 \\
\end{array}$ & $\begin{array}{l}59.67^{\mathrm{a}} \\
\pm 0.13 \\
\end{array}$ & $\begin{array}{l}8.36^{\mathrm{a}} \\
\pm 1.72 \\
\end{array}$ & $\begin{array}{l}8.30^{\mathrm{a}} \\
\pm 1.88 \\
\end{array}$ & $\begin{array}{l}8.46^{\mathrm{a}} \\
\pm 1.53 \\
\end{array}$ & $\begin{array}{l}8.16^{\mathrm{a}} \\
\pm 1.99 \\
\end{array}$ & $\begin{array}{l}8.08 \text { ab } \\
\pm 1.86 \\
\end{array}$ & $\begin{array}{l}8.20^{\mathrm{a}} \\
\pm 1.62 \\
\end{array}$ & $\begin{array}{l}53.74^{\mathrm{a}} \\
\pm 0.18 \\
\end{array}$ & $\begin{array}{l}0.91^{\mathrm{a}} \\
\pm 0.01 \\
\end{array}$ & $\begin{array}{l}7.32^{\mathrm{a}} \\
\pm 0.10 \\
\end{array}$ & $\begin{array}{l}5.42 \mathrm{a} \\
\pm 0.10 \\
\end{array}$ & $\begin{array}{l}6.49^{\mathrm{b}} \pm \\
0.29\end{array}$ & $\begin{array}{l}5.46^{\mathrm{b}} \\
\pm 0.29 \\
\end{array}$ & $\begin{array}{l}1.03 \text { ab } \\
\pm 0.06 \\
\end{array}$ & 26.12 \\
\hline 5 & \multirow{2}{*}{$\begin{array}{c}0 \\
(75 \%)\end{array}$} & \multirow{2}{*}{$\begin{array}{c}0 \\
(120 \%)\end{array}$} & $\begin{array}{l}1.76^{\mathrm{b}} \\
\pm 0.01\end{array}$ & $\begin{array}{l}13.32^{\mathrm{c}} \\
\pm 0.60 \\
\end{array}$ & $\begin{array}{l}57.17^{\mathrm{b}} \\
\pm 0.49 \\
\end{array}$ & $\begin{array}{l}7.911^{\mathrm{a}} \\
\pm 1.91 \\
\end{array}$ & $\begin{array}{l}7.97^{\mathrm{a}} \\
\pm 1.88 \\
\end{array}$ & $\begin{array}{l}8.49^{\mathrm{a}} \\
\pm 1.64 \\
\end{array}$ & $\begin{array}{l}7.88^{\mathrm{a}} \\
\pm 2.02 \\
\end{array}$ & $\begin{array}{l}8.50^{\mathrm{ab}} \\
\pm 1.50 \\
\end{array}$ & $\begin{array}{l}8.38^{\mathrm{a}} \\
\pm 1.42 \\
\end{array}$ & \multirow{2}{*}{$\begin{array}{l}47.42^{\mathrm{b}} \\
\pm 0.26\end{array}$} & \multirow{2}{*}{$\begin{array}{l}0.79^{c} \\
\pm 0.02\end{array}$} & \multirow{2}{*}{$\begin{array}{l}5.81^{\mathrm{b}} \\
\pm 0.14\end{array}$} & \multirow{2}{*}{$\begin{array}{l}5.46^{\mathrm{a}} \\
\pm 0.05\end{array}$} & \multirow{2}{*}{$\begin{array}{c}5.99^{\mathrm{b}} \pm \\
0.19\end{array}$} & \multirow{2}{*}{$\begin{array}{l}4.86^{\mathrm{c}} \\
\pm 0.17\end{array}$} & \multirow{2}{*}{$\begin{array}{l}1.13 \mathrm{ab} \\
\pm 0.03\end{array}$} & \multirow{2}{*}{34.53} \\
\hline 6 & & & $\begin{array}{l}1.72^{\mathrm{b}} \\
\pm 0.02\end{array}$ & $\begin{array}{l}13.08^{c} \\
\pm 0.62\end{array}$ & $\begin{array}{l}57.09^{\mathrm{b}} \\
\pm 0.21\end{array}$ & $\begin{array}{l}7.63^{\mathrm{a}} \\
\pm 1.84\end{array}$ & $\begin{array}{l}7.52^{\mathrm{a}} \\
\pm 1.84\end{array}$ & $\begin{array}{l}8.50^{\mathrm{a}} \\
\pm 1.75\end{array}$ & $\begin{array}{l}7.77^{\mathrm{a}} \\
\pm 1.89\end{array}$ & $\begin{array}{l}8.06^{\mathrm{ab}} \\
\pm 1.86\end{array}$ & $\begin{array}{l}7.99 \mathrm{a} \\
\pm 1.54\end{array}$ & & & & & & & & \\
\hline
\end{tabular}

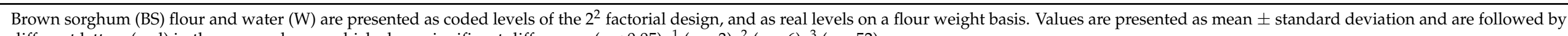
different letters $(a-d)$ in the same column, which show significant differences $(p<0.05) .{ }^{1}(n=3),{ }^{2}(n=6),{ }^{3}(n=52)$. 
The WS experimental design explained $97 \%$ of crumb moisture variation while for appearance, texture, and overall acceptability, 77,91 , and $96 \%$ were explained, respectively. For BS, the experimental design explained $99 \%$ of the moisture crumb variation. The models showed the effect of W on the moisture content of GFB prepared with WS and BS, indicating that the higher the $\mathrm{W}$ concentration in the formulation, the greater the crumb moisture. WS had a negative effect on appearance, texture, and overall acceptance scores, while $\mathrm{W}$ had a positive effect on texture and overall acceptance scores. Moreover, there was no interaction between the sorghum flours and $\mathrm{W}$ in terms of the physical properties and acceptability of GFB, contradicting the initial hypothesis of this study.

No significant factorial design regression models were obtained for the other variables.

Figure 1 shows the appearance of the bread made with WS and BS. As expected from the natural color of the pericarp of the grains, the use of WS resulted in bread with a lighter crumb color (not evaluated instrumentally) than those obtained using BS. The formulations with 100\% BS (Trials 2 and 4) were darker in color (not evaluated instrumentally) than the others, while the formulations made entirely with WS or BS (trials 2 and 4) had fewer tunnels and smaller and more evenly distributed alveoli than the formulations made with the addition of potato starch (Trials 1,3, 5 and 6).

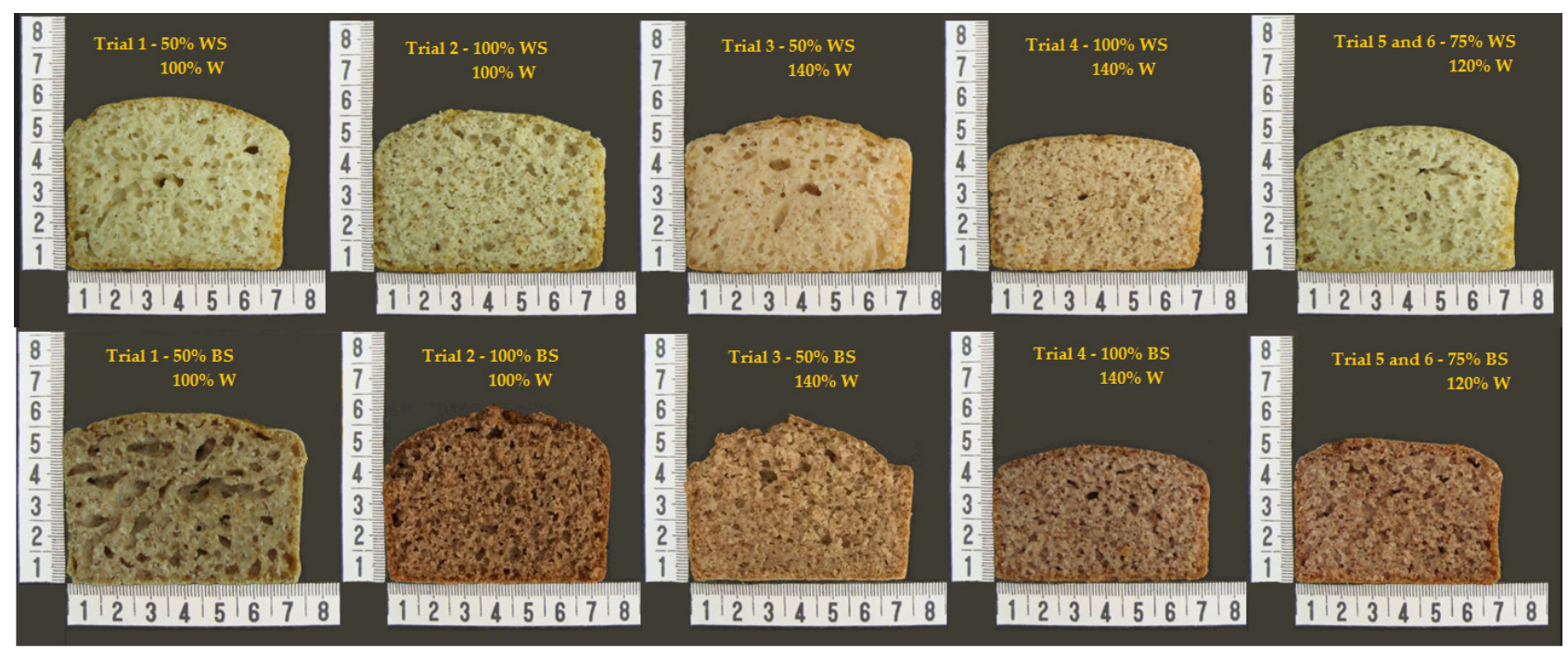

Figure 1. Representative images of gluten-free bread formulations prepared using a 22-factorial design with two center points to study the effects of white sorghum (WS) and bronze sorghum (BS) flour and water (W) levels on a flour weight basis. A cm measuring scale was used.

\subsection{Relationships between Physical, Sensory, and Proximate Composition of GFB}

Figure 2 shows the relationships between the physical, sensory, and proximate composition properties of the bread samples, whereby the two MFA factors explained $95.07 \%$ and $87.89 \%$ of the total variation of the GFB made with WS and BS, respectively. For the WS-based GFB, Factor 1 was correlated with sensory properties when blended with potato starch, describing the 50WS:100W and 75WS:120W samples. By contrast, the loaf specific volume, crumb firmness, protein, lipid, and fiber contents described the 100WS:100W sample, which had the highest WS concentration. Factor 2 was correlated with the moisture content due to the to the fact that it used the highest $\mathrm{W}$-level when referring to sample 50WS:140W (Figure 2a,b).

For the BS-based GFB, Factor 1 was positively correlated with flavor and overall acceptance and crumb moisture when BS was blended with potato starch and when the highest $\mathrm{W}$ level was added, i.e., the 50BS:140W sample. By contrast, the loaf specific volume, crumb firmness, protein, lipid, and fiber contents explained the 100BS:100W sample. Factor 2 was explained by the moisture content due to the 100BS:140W sample (Figure 2c,d). 
Figure 3 shows the dendrogram, which illustrates the existence of two groups of GFB made with WS. The first group contains three samples: 50WS:100W, 50WS:140W, and 75WS:120W, while the second group contains two products made with 100WS:100W and $100 \mathrm{WS}: 140 \mathrm{~W}$. In addition, a moderate clustering was seen since the WS model presented a cophenetic correlation coefficient value of 0.612 . On the other hand, Figure $3 \mathrm{~b}$ identified the existence of three groups between the GFBs based on BS. The first one only identified the 100BS:100W sample, the second one contained two samples: 50BS:100W and 75BS:120W, while the third one contained two samples with the highest W-levels: 50BS:140W and 100BS:140W. In addition, there was a high degree of clustering since the BS model presented a cophenetic correlation coefficient value of 0.734 .
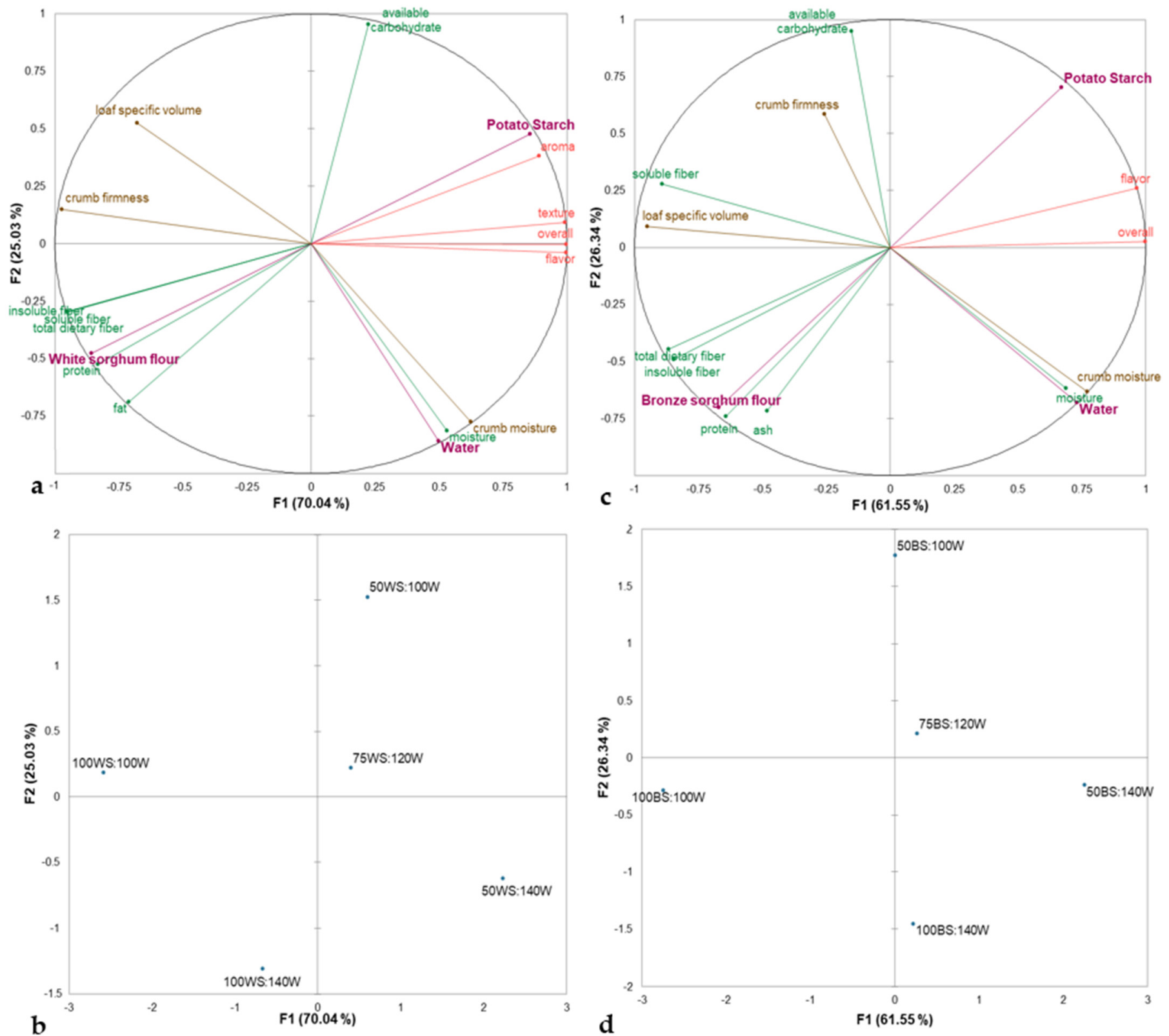

Figure 2. Multiple factor analysis correlating the physical (in brown), sensorial (in red), and proximate composition (in green) the properties of gluten-free bread with different water (W) levels and based on white sorghum (WS in sub-figures a,b) or bronze sorghum (BS in sub-figures c,d) flours. Bread ID: WS, white sorghum; BS, bronze sorghum; W, water. The letters and numbers indicate the ingredient proportions in the flour weight basis $(\mathrm{g} / 100 \mathrm{~g})$. 

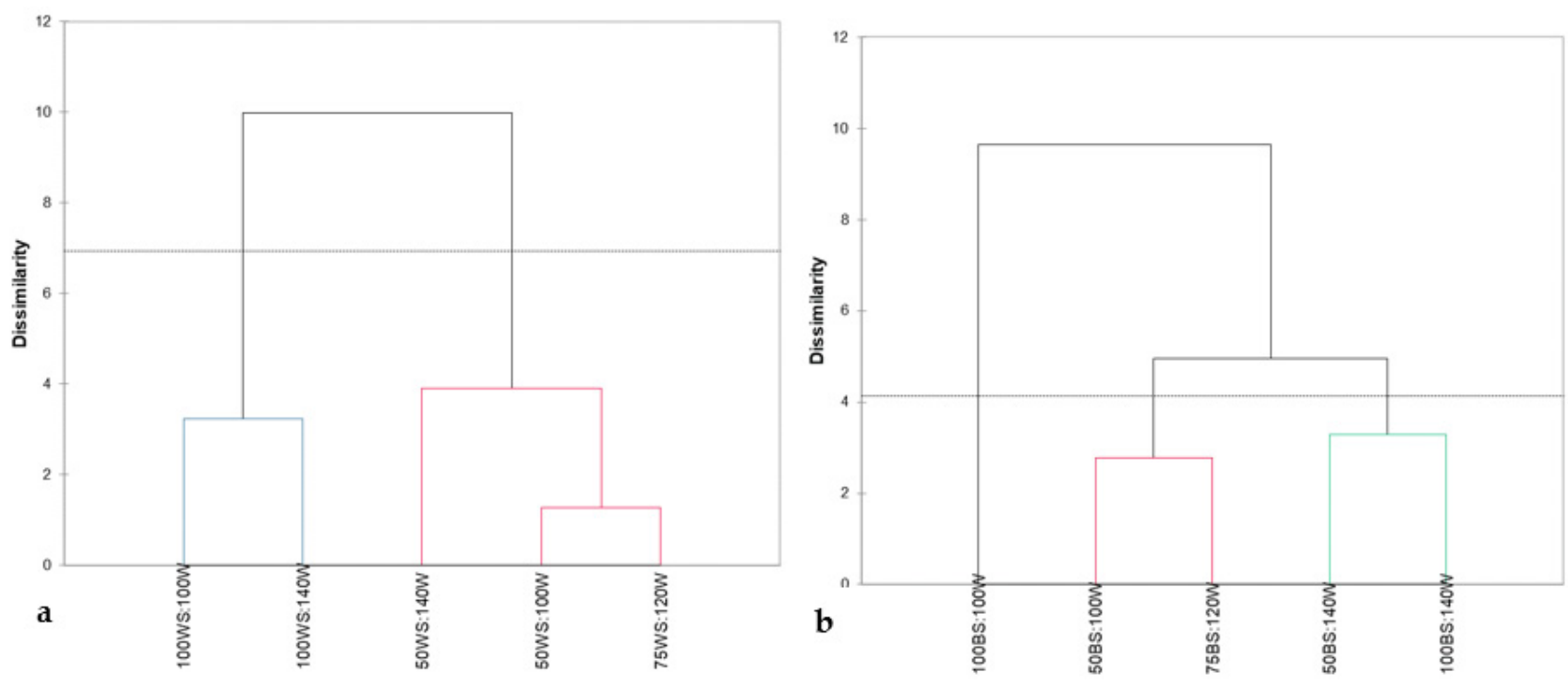

Figure 3. Dendrogram obtained by hierarchical cluster analysis for data of gluten-free bread based on (a) white sorghum (WS) and (b) bronze sorghum (BS) flours and different water (W) levels. Bread ID: WS, white sorghum; BS, bronze sorghum; $\mathrm{W}$, water. The letters and numbers indicate the ingredient proportions in the flour weight basis $(\mathrm{g} / 100 \mathrm{~g})$.

\section{Discussion}

The specific volumes of the experimental formulations are comparable to those reported in other studies, such as $1.85 \mathrm{~cm}^{2} / \mathrm{g}$ for GFB prepared with $100 \%$ rice flour [23]. However, Rose et al. [27] reported lower values of specific volumes for different breads made with wheat flour in combination with $\mathrm{SF}$, with values of $1.30 \mathrm{~cm}^{3} / \mathrm{g}$ for GFB prepared with $75 \% \mathrm{WS}$ and $1.40 \mathrm{~cm}^{2} / \mathrm{g}$ for GFB prepared with $75 \%$ BS. According to Trappey et al. [28], the increase in SF content and consequently fiber content is a factor that is mainly responsible for the decrease in the specific volume of GFB prepared with SF. However, this effect was not observed in this study, possibly because of the water adjustment that was also conducted.

Previous studies showed that when up to $70 \%$ SF is used in combination with rice, potato, cassava, or corn starches, GFB with promising physical characteristics could be produced $[29,30]$. The results of the present study show that it is possible to use both $100 \%$ SF and $75 \%$ SF in combination with potato starch and obtain GFB with greater volume and softness.

Regarding acceptability, Drub et al. [31] reported high scores ( $>7$ in a $10 \mathrm{~cm}$ hybrid hedonic scale) for appearance, color, texture, and overall liking of GFB made with $100 \%$ WS. Our results show that it is possible to obtain scores greater than 7 for these attributes using $100 \%$ BS in the formulation of GFB. When comparing formulations made with WS or BS and conventional GFB formulations in terms of acceptability, the GFB resulting from Trials 1, 3, 5, and 6 obtained acceptability scores similar to those obtained by GFB prepared under the same experimental conditions with $100 \%$ rice flour and by GFB prepared with $50 \%$ rice flour and $50 \%$ potato starch, ranging from 7.6 to 8.5 [29]. Therefore, GFB made with $50 \%$ and $75 \%$ whole grain SF has acceptability similar to conventional GFB.

To verify whether there was an increase in the nutritional composition of the GFBs made with WS or BS, they were compared with two conventional GFB formulations. Sandri et al. [22] prepared GFB with $100 \%$ rice flour containing $52.2 \%$ moisture, $1.2 \%$ ash, $4.1 \%$ lipid, $5.0 \%$ protein, $2.1 \%$ dietary fiber, and $35.4 \%$ available carbohydrates. Santos et al. [23] made GFB with 50\% rice flour and 50\% potato starch containing $48.6 \%$ moisture, $1.32 \%$ ash, $4.2 \%$ lipid, $4.10 \%$ protein, $2.30 \%$ total fiber, and $39.5 \%$ available carbohydrates. Observing the composition of these conventional breads, GFB made with $75 \%$ and 100\% WS/BS showed an increase in protein and fiber content. 
According to the criteria of Codex Alimentarius [32], these GFBs made with 50\% and $75 \%$ WS/BS can be classified as a source of fiber because the fiber content is higher than $3 \mathrm{~g}$ per $100 \mathrm{~g}$, while GFB made with $100 \%$ WS/BS can be classified as high in fiber because the content of this nutrient is higher than $6 \mathrm{~g}$ per $100 \mathrm{~g}$.

Compared to the bread solely made of BS flour that was developed by Hager et al. [33], the GFB made from our formulations containing 100\% WS or BS have a better appearance and are characterized by a crumb of uniform distribution of alveoli. This result is possibly due to the higher levels of water used in the formulations (100 to $140 \%$ ) since Hager et al. [33] used a concentration of $95 \%$ water fwb and, according to Capriles and Arêas [18], the increase in water content is important to ensure the appropriate conditions of the dough viscosity, starch gelatinization, and protein denaturation during the baking process.

The formulations developed in this study also contained hydrocolloids (xanthan gum and carboxymethylcellulose), unlike those presented by Hager et al. [33], which possibly contributed to the better appearance because according to Salehi [34] and Amboni et al. [35], the use of hydrocolloids can positively affect the quality of gluten-free products.

Results show the potential of using sorghum to produce acceptable whole grain GFB, which is an innovation considering the actual market reality [1], and this is a promising development in the goal to meet the consumer need for better flavor, texture and healthiness in GFB [36].

\section{Conclusions}

Our study highlights the potential of using sorghum to produce whole grain GFB, giving valuable solutions to meet consumer and producer demands for quality, healthy, and sensorily acceptable GFB.

The use of different sorghum cultivars resulted in GFB with diverse characteristics due to the intrinsic features of each type of obtained bread. It was proven that it is possible to make GFB with up to $100 \%$ BS and with $75 \%$ WS without affecting their sensory acceptance since these formulations achieved scores greater than 7 on a $10 \mathrm{~cm}$ hybrid hedonic scale. In addition, the use of $75 \%$ and $100 \%$ sorghum flour resulted in an increase in the protein and fiber content of GFB. Increasing the water levels is required to obtain acceptable GFB made with $100 \%$ BS or WS.

Reflecting the nutrition and sensory features, we consider formulations containing $75 \%$ WS $/ 120 \%$ water and 100\% BS/140\% water to be promising formulations.

Author Contributions: A.C.L.C.: methodology, data curation, investigation, visualization, writingoriginal draft preparation; E.A.: data curation, investigation, methodology, writing — original draft preparation; F.S.: data curation, investigation, methodology, writing-original draft preparation; V.Q.: writing - review and editing, funding acquisition; A.C.-S.: data curation, writing-review and editing; U.K.-K.: writing-review and editing; V.C.: conceptualization, methodology, data curation, investigation, visualization, writing —original draft preparation, writing-review and editing, supervision, funding acquisition. All authors have read and agreed to the published version of the manuscript.

Funding: This research was funded by the São Paulo Research Foundation (FAPESP), grant numbers (2012/17838-4) and (2019/15359-0), and Embrapa.

Institutional Review Board Statement: This study was conducted according to the guidelines of the Declaration of Helsinki and was approved by the Ethics Committee of the Federal University of São Paulo (protocol code 203.145, approved on 01/03/2013).

Informed Consent Statement: Informed consent was obtained from all subjects involved in the study.

Data Availability Statement: The data presented in this study are available on request from the corresponding author.

Acknowledgments: The authors deeply acknowledge the volunteers who participated in this study, the Brazilian Agricultural Research Corporation-Embrapa Milho e Sorgo, and the food companies for supplying the ingredient samples. 
Conflicts of Interest: The authors declare no conflict of interest. The funders had no role in the design of the study; in the collection, analyses, or interpretation of data; in the writing of the manuscript; or in the decision to publish the results.

\section{References}

1. Aguiar, E.V.; Santos, F.G.; Krupa-kozak, U.; Capriles, V.D. Nutritional facts regarding commercially available gluten-free bread worldwide: Recent advances and future challenges. Crit. Rev. Food Sci. Nutr. 2021, 1-13. [CrossRef]

2. Fajardo, V.; González, M.P.; Martínez, M.; Samaniego-Vaesken, M.L.; Achón, M.; Úbeda, N.; Alonso-Aperte, E. Updated food composition database for cereal-based gluten free products in spain: Is reformulation moving on? Nutrients 2020, $12,2369$. [CrossRef]

3. Lappi, V.M.; Mottas, A.; Sundström, J.; Neal, B.; Löf, M.; Rådholm, K. A comparison of the nutritional qualities of supermarket's own and regular brands of bread in sweden. Nutrients 2020, 12, 1162. [CrossRef]

4. Tres, A.; Tarnovska, N.; Varona, E.; Quintanilla-Casas, B.; Vichi, S.; Gibert, A.; Vilchez, E.; Guardiola, F. Determination and Comparison of the Lipid Profile and Sodium Content of Gluten-Free and Gluten-Containing Breads from the Spanish Market. Plant Foods Hum. Nutr. 2020, 75, 344-354. [CrossRef] [PubMed]

5. Roman, L.; Belorio, M.; Gomez, M. Gluten-Free Breads: The Gap Between Research and Commercial Reality. Compr. Rev. Food Sci. Food Saf. 2019, 18, 690-702. [CrossRef] [PubMed]

6. Santos, F.G.; Aguiar, E.V.; Capriles, V.D. Analysis of ingredient and nutritional labeling of commercially available gluten-free bread in Brazil. Int. J. Food Sci. Nutr. 2019, 70, 562-569. [CrossRef] [PubMed]

7. USDA. Agriculture USD of Grain: World Markets and Trade. Foreign Agricultural Service. Available online: https://apps.fas. usda.gov/psdonline/circulars/grain.pdf (accessed on 1 July 2021).

8. Rodrigues, J.A.S. Sorghum Has a High Potential for Grain Production, in Addition to Its Extraordinary Ability to Withstand Environmental Stresses, Being An Excellent Option for Grain Production in Situations of Water Deficit and Low Soil Fertility. Sistema de Produção, 2: Cultivo do Sorgo. Embrapa Milho e Sorgo. Available online: https://www.spo.cnptia.embrapa.br/conteudo?p_ p_id=conteudoportlet_WAR_sistemasdeproducaolf6_1ga1ceportlet\&p_p_lifecycle=0\&p_p_state=normal\&p_p_mode=view\& p_P_col_id=column-1\&p_P_col_count=1\&p_r_p_-76293187_sistemaProducaoId=8301\&p_r_p_-996514994_topicoId=9 (accessed on 1 July 2021).

9. Kumari, P.K.; Umakanth, A.V.; Narsaiah, T.B.; Uma, A. Exploring anthocyanins, antioxidant capacity and $\alpha$-glucosidase inhibition in bran and flour extracts of selected sorghum genotypes. Food Biosci. 2021, 41, 100979. [CrossRef]

10. Punia, H.; Tokas, J.; Malik, A.; Satpal, S.S. Characterization of phenolic compounds and antioxidant activity in sorghum [Sorghum bicolor (L.) Moench] grains. Cereal Res. Commun. 2021, 49, 343-353. [CrossRef]

11. Martino, H.S.D.; Tomaz, P.A.; Aguiar, M.É.; da Conceição, L.L.; Oliveira, D.S.; Queiroz, V.A.V.; Rodrigues, J.A.S.; Pirozi, M.R.; Pinheiro Sant-Ana, H.M.; Ribeiro, S.M.R. Chemical characterization and size distribution of sorghum genotypes for human consumption. Rev. Inst. Adolfo Lutz 2012, 71, 337-344.

12. Ari, A.P.; Miller, R.; Jaffe, T.; Koppel, K.; Ehmke, L. Sensory profile and quality of chemically leavened gluten-free sorghum bread containing different starches and hydrocolloids. J. Sci. Food Agric. 2019, 99, 4391-4396. [CrossRef]

13. Nieto-Mazzocco, E.; Saldaña-Robles, A.; Franco-Robles, E.; Rangel-Contreras, A.K.; Cerón-García, A.; Ozuna, C. Optimization of sorghum, rice, and amaranth flour levels in the development of gluten-free bakery products using response surface methodology. J. Food Process. Preserv. 2020, 44, 1-9. [CrossRef]

14. Ogunsakin, O.A.; Banwo, K.; Ogunremi, O.R.; Sanni, A.I. Microbiological and physicochemical properties of sourdough bread from sorghum flour. Int. Food Res. J. 2015, 22, 2610-2618.

15. Soares, R.R.A.; Vasconcelos, C.M.; de Oliveira, M.V.; Minim, V.P.R.; Queiroz, V.A.V.; Barros, F. Starch digestibility and sensory acceptance of gluten free foods prepared with tannin sorghum flour. Pesqui. Agropecu. Bras. 2019. [CrossRef]

16. Pezzali, J.G.; Suprabha-Raj, A.; Siliveru, K.; Aldrich, C.G. Characterization of white and red sorghum flour and their potential use for production of extrudate crisps. PLoS ONE 2020, 15, e4940. [CrossRef] [PubMed]

17. Banu, I.; Aprodu, I. Assessing the performance of different grains in gluten-free bread applications. Appl. Sci. 2020, 10, 8772. [CrossRef]

18. Capriles, V.D.; Arêas, J.A.G. Novel approaches in gluten-free breadmaking: Interface between food science, nutrition, and health Compr. Rev. Food Sci. Food Saf. 2014, 13, 871-890. [CrossRef]

19. Osella, C.; Torre, M.D.L.; Sánchez, H. Safe Foods for Celiac People. Food Nutr. Sci. 2014, 5, 787-800. [CrossRef]

20. Akin, P.A.; Bean, S.R.; Smith, B.M.; Tilley, M. Factors Influencing Zein-Whole Sorghum Flour Dough Formation and Bread Quality. J. Food Sci. 2019, 84, 3522-3534. [CrossRef]

21. AOAC. Official Methods of Analysis, 18th ed.; Association of Official Analytical Chemist: Rockville, MD, USA, 2005.

22. Sandri, L.T.B.; Santos, F.G.; Fratelli, C.; Capriles, V.D. Development of gluten-free bread formulations containing whole chia flour with acceptable sensory properties. Food Sci. Nutr. 2017, 5, 1021-1028. [CrossRef]

23. Santos, F.G.; Fratelli, C.; Muniz, D.G.; Capriles, V.D. Mixture Design Applied to the Development of Chickpea-Based Gluten-Free Bread with Attractive Technological, Sensory, and Nutritional Quality. J. Food Sci. 2018, 83, 188-197. [CrossRef]

24. AACC. Approved Methods of Analysis, 11th ed.; American Association of Cereal Chemists: Washington, DC, USA, 2010. 
25. Villanueva, N.D.M.; Petenate, A.J.; Da Silva, M.A.A.P. Performance of three affective methods and diagnosis of the ANOVA model. Food Qual. Prefer. 2000, 11, 363-370. [CrossRef]

26. Barros Neto, B.; Bruns, R.E.S. Como Fazer Experimentos (Report No.: 3 ed.); Editora da Unicamp: Campinas, Brazil, 2007.

27. Rose, D.J.; Williams, E.; Mkandawire, N.L.; Weller, C.L.; Jackson, D.S. Use of whole grain and refined flour from tannin and non-tannin sorghum (Sorghum bicolor (L.) Moench) varieties in frybread. Food Sci. Technol. Int. 2014, 20, 333-339. [CrossRef] [PubMed]

28. Trappey, E.F.; Khouryieh, H.; Aramouni, F.; Herald, T. Effect of sorghum flour composition and particle size on quality properties of gluten-free bread. Food. Sci. Technol. Int. 2015, 21, 188-202. [CrossRef] [PubMed]

29. Onyango, C.; Mutungi, C.; Unbehend, G.; Lindhauer, M.G. Modification of gluten-free sorghum batter and bread using maize, potato, cassava or rice starch. LWT-Food Sci. Technol. 2011, 44, 681-686. [CrossRef]

30. Schober, T.J.; Messerschmidt, M.; Bean, S.R.; Park, S.H.; Arendt, E.K. Gluten-free bread from sorghum: Quality differences among hybrids. Cereal Chem. 2005, 82, 394-404. [CrossRef]

31. Drub, T.F.; Santos, F.G.; Centeno, A.C.L.S.; Capriles, V.D. Sorghum, millet and pseudocereals as ingredients for gluten-free whole-grain yeast rolls. Int. J. Gastron. Food Sci. 2021, 23, 293. [CrossRef]

32. Codex Alimentarius Comission. Guidelines for Use of Nutrition and Health Claims_CAC/GL 23-1997. 2013. Available online: http: / / www.fao.org/fao-who-codexalimentarius/sh-proxy/en/?lnk=1\&url=https\%253A\%252F\%252Fworkspace.fao. org\%252Fsites\%252Fcodex\%252FStandards\%252FCXG\%2B23-1997\%252FCXG_023e.pdf (accessed on 1 July 2021).

33. Hager, A.S.; Wolter, A.; Czerny, M.; Bez, J.; Zannini, E.; Arendt, E.K.; Czerny, M. Investigation of product quality, sensory profile and ultrastructure of breads made from a range of commercial gluten-free flours compared to their wheat counterparts. Eur. Food Res. Technol. 2012, 235, 333-344. [CrossRef]

34. Salehi, F. Improvement of gluten-free bread and cake properties using natural hydrocolloids: A review. Food Sci. Nutr. 2019, 7, 3391-3402. [CrossRef]

35. Amboni, R.; do Nascimento, A.B.; Fiates, G.M.R.; Teixeira, E. New Perspectives on Gluten-Free Food Products. Available online: https:/ / www.researchgate.net/publication/236993192_New_Perspectives_on_Gluten-Free_Food_Products (accessed on 1 July 2021).

36. Alencar, N.M.M.; de Araújo, V.A.; Faggian, L.; da Silveira Araújo, M.B.; Capriles, V.D. What about gluten free products? An insight on celiac consumers' opinions and expectations. J. Sens. Stud. 2021, e12664. [CrossRef] 